\title{
Evaluation of Chenopodium album Linn. Crude Methanolic Leaf Extract for Central Antinociceptive Activity in Albino Mice using the Hot Plate Test
}

\section{Sibusisiwe Magama1 ${ }^{2}$, Asita OkorieAsita1}

${ }^{1}$ Department of Biology, National University of Lesotho, P.O. Roma 180 Maseru, Lesotho, Southern Africa.

\begin{abstract}
The aim of study was to evaluate the crude leaf extract of Chenopodium album for central antinociceptive activity using inbred NIH albino mice. No mortalities were observed during the 14 day period in any of the 4 groups of 5 mice per group orally given $1,2,3$, and $5 \mathrm{~g} / \mathrm{kg}$ bw respectively. It was therefore assumed that the $\mathrm{LD}_{50}$ was higher than $5 \mathrm{~g} / \mathrm{kg}$ bw. Eddy's hot plate test for antinociception using 0, 50, $100 \mathrm{and} 150 \mathrm{mg} / \mathrm{kg} \mathrm{bw}$ and standard drug Aspirin $(150 \mathrm{mg} / \mathrm{kg} \mathrm{bw})$ orally administered revealed that both Aspirin and the extract at 100 and at $150 \mathrm{mg} / \mathrm{kg}$ bw exhibited significant $(\mathrm{P}<0.05)$ dose-dependent antinociception compared with the negative control at the seven time intervals; 30, 60, 120,180, 240,300, 360 minutes. The maximum antinociception (71.47\%) for the $150 \mathrm{mg} / \mathrm{kg}$ bw group being at 30 minutes after administration and statistically not different from that of Aspirin $(67.44 \%)$ at the same time interval. Between 30 and 180 minutes after oral administration of test substances, antinociception due to $C$. album extract $(150 \mathrm{mg} / \mathrm{kg}$ bw) was statistically not different fromthatduetoAspirin. Thereafter Aspirin remained more efficacious than the extracttill the end of experiment at 360 minutes; a parallel shift from 240 minutes suggesting a similar mechanism of antinociception.
\end{abstract}

KEYWORDS: Hotplate Latency, Antinociception, Chenopodium album, Phytochemicals

\section{INTRODUCTION}

The hot plate test uses acute non-inflammatory neurological pain induced by the noxious thermal stimulus to study central nociception and antinociception (Ibironke and Ajiboye, 2007). Acute pain is intense, lasts for a relatively short time, and its presence is usually an indication of a severe injury (Linn, 1984). Acute pain is useful in protecting the tissues against noxious stimuli (Almeida et al., 2001). Nociception is the neural process of encoding and processing noxious stimuli, which can be developed by thermal, chemicals and physical pressure (Schaible, 2006). This activity is initiated by nociceptors which are also known as pain receptors. Nociceptors are embedded in the skin and internally in joints. They can detect mechanical, thermal or chemical changes above a set body threshold anywhere in the body where they are located. Once stimulated, a nociceptor sends the signal to the central nervous system through the spinal cord (Schaible, 2006).
Antinociception is the reduction in the sensitivity and detection of such pre-existing painful stimuli. It is also known as analgesia and it can be achieved by the use of analgesics. Analgesics are therefore, any substances which decrease pain sensation usually by increasing the pain threshold to external stimuli (Tripathi, 2004). Currently used analgesics include opioids such as morphine and heroine. In addition to relieving pain, these narcotic drugs cause drowsiness and dependence. On the other hand non-opioid analgesics, the Non-Steroidal Anti-inflammatory Drugs (NSAIDs), such as aspirin and paracetamol are non-narcotics but have other side effects such as gastric erosion, liver and kidney malfunction (Brunton et al., 2008; Zulfiker et al., 2010). Aspirin is readily available and is the most widely consumed NSAID (Brunton et al., 2008).

The World Health Organisation (WHO) encourages the use of herbal medicine as an essential component of primary health care in many developing countries since natural herbal products as alternative therapeutic options are cheap, abundant, readily

This article is published under the terms of the Creative Commons Attribution License 4.0

Author(s) retain the copyright of this article. Publication rights with Alkhaer Publications.

Published at: http://www.ijsciences.com/pub/issue/2017-06/

DOI: 10.18483/ijSci.1310; Online ISSN: 2305-3925; Print ISSN: 2410-4477 
available, and less toxic compared to conventional allopathic medicines (Kaur and Jaggi, 2010; Dattaet al., 2014; Jami et al., 2014). Of the very many different plant species that form the diverse flora in Lesotho, over 2000 are used directly and indirectly as food and as medicinal remedies for various ailments (Maliehe and Oehrlein,1997). Chenopodium album (seruoe in Sesotho) is a herbaceous vegetable plant species of about $30-70 \mathrm{~cm}$ in height, with a stout central stem and ascending lateral branches (Maliehe and Oehrlein, 1997; Sikarwar et al., 2013). It is one of the most widely distributed species of weeds across many climatic conditions in the world with average temperatures ranging from $5-30^{\circ} \mathrm{C}$ (Biswas et al., 2013). In Lesotho, Chenopodium album can be found in all the four ecological zones of the kingdom throughout the year; young leaves are consumed as a vegetable while the whole plant is used as a medicine in the rural communities to improve appetite, as a laxative, diuretic, tonic, treatment of biliousness, eye diseases and as an analgesic for abdominal pain (Maliehe and Oehrlein, 1997). The plant is rich in proteins, vitamins $\mathrm{A}$ and $\mathrm{C}$, calcium, phosphorus, iron, potassium and phytoconstituents such as phenolic compounds (simple phenolics and polyphenolics, cinnamic acid amides), alkaloids, monoterpenoids and saponins (Sikarwaret al., 2013; Agrawal et al., 2014).

Chenopodium album is important in Southern African traditional medicine but we are not aware of studies that have been done on its toxicity and central analgesic effects. Studies that we have seen are only those on peripheral analgesic activity of $C$. album (Ahmad, et al., 2012; Dai et al., 2002; Begum et al., 2013). Therefore, in the present study, the crude methanolic extract prepared from leaves of C. album was assessed for toxicity and central antinociceptive activity in albino mice using the hot plate test (Ibironke and Ajiboye, 2007). This test measures the complex response to non-inflammatory, acute nociceptive stimulation and is one of the wellvalidated and widely used model for studying neurological pain and central antinociceptive activity (Ibironke and Ajiboye, 2007).

\section{MATERIALS AND METHODS \\ 2.1 Plant material}

Chenopodium album was collected from the bush around the National University of Lesotho, Roma campus and from the adjacent bushes in Hata-Butle, east of the National University of Lesotho Roma campus and was authenticated by the curator of the herbarium at the Department of Biology. Leaves were separated from the rest of the plant and used in the study.
2.2 Preparation of crude extract of $C$. album leaves Leaves of $C$. album were dried at $35^{\circ} \mathrm{C}$ in a fanned oven (Labcon) until they were brittle, then they were ground to powder in a pulveriser (Kenwood). The powdered leaf material (500 grams) was soaked in 95\% methanol (v/v) in distilled water $(1.5$ Litres) for three days followed by vacuum filtration of the extract through a Whatman \#1 filter paper (Kent, England). The solvent was then evaporated from the extract under vacuum using a rotary evaporator (Gallenkamp) and the remaining water was removed by drying the extract in a fanned oven (Labcon) set at $30^{\circ} \mathrm{C}$.

\subsection{Animals}

Inbred NIH albino mice between 8-10 weeks weighing 27-30 grams, bred and kept in the animal house of the Department of Biology were used for the study. The animals were allowed free access to food (Meadow sheep pellets) and water ad-libitum (Asita et al., 2008).

\subsection{Toxicity assay}

Five groups of five mice per group, (25-30grams each) were set up and the mice were fasted for 12 hours prior to the morning of the oral administration of test substances as follows: Group 1 was the negative control group and the mice were given $5 \mathrm{~mL} / \mathrm{kg}$ bw of $6 \%$ Tween-80 (v/v solution in distilled water). Mice in groups 2, 3, 4 and 5, were given $C$. album extract at $1,2,3$ and $5 \mathrm{~g} / \mathrm{kg}$ bw respectively (Yadav et al., 2011). The mice were weighed prior to administration and acute toxicity was determined by monitoring them for deaths and slow movement for 24 hours after the administration of test substances. Mice were then re-weighed and monitored daily for the next 14 days for any delayed toxicity (Morales et al., 2014; Obidah et al., 2014). No mouse died even in the $5 \mathrm{~g} / \mathrm{kg}$ bw group therefore the extracts were considered non toxic when administered orally at the dosage range used.

For the determination of the antinociceptive activity of the C. album crude leaf extract, the following safe oral doses, which are well below the highest concentration used in the toxicity tests, based on Datta et al., 2014 were chosen as follows: 50, 100 and $150 \mathrm{mg} / \mathrm{kg}$ bw.

\subsection{Eddy's hotplate nociception test}

Central analgesic activity of the $C$. album extract was evaluated using the hot plate nociception test (Bhattacharya et al., 2014; Abdullahi et al., 2013) in which the mice were fasted for 12 hours with provision of clean water ad libitum prior to the experiment (Omeh and Ezega, 2010). In this assay, 
test substances and controls were administered orally (Yadav et al., 2011; Sajeesh and Parimelazhagan, 2014). Briefly, five groups of mice of both sexes, each group containing five mice (replicates) were set up as follows; (Groups 1, 2 and 3 were orally given 50,100 and $150 \mathrm{mg} / \mathrm{kg}$ bw of extract respectively. Group 4 was the negative control group, orally given $5 \mathrm{~mL} / \mathrm{kg}$ bw of $6 \%$ Tween- $80 \mathrm{v} / \mathrm{v}$ solution in distilled water. Group 5 was the positive control group also orally administered with Aspirin at $150 \mathrm{mg} / \mathrm{kg}$ bw (Shanmugasundaram and Venkataraman, 2005; Chyad, 2017; Yadav et al., 2011); Rajalakshimi et al., 2015). Each mouse served as its own control and the "initial reaction time" was determined before treatment (Sajeesh and Parimelazhagan, 2014).The hot plate latency for each mouse was determined by placing the mouse in a plexiglass cylinder of diameter $20 \mathrm{~cm}$ and height $25 \mathrm{~cm}$ on the heated surface of a hot plate maintained at $55 \pm 0.5^{\circ} \mathrm{C}$ (Jami et al., 2014). The time between placement of the mouse on the hotplate and the occurrence of pain sensation in the form of either a hind paw lick or a jump off the surface (whichever appeared first) was recorded as the hotplate latency (Jamiet al., 2014; Sajeesh and Parimelazhagan, 2014). A cut-off time of 10 seconds (regarded as complete analgesia) was observed in order to avoid thermal injury to the animals which meant that mice with a basal latency of more than 10 seconds were not included in the study (Barua et al., 2010). The base line latency of nociceptive response was the reaction time before oral treatment (that is, reactiontime at time 0 ). The hot plate latencies for the mice were determined at 30 minutes intervals up to 60 minutes, thereafter at 60 minute intervals up to 360 minutes after oral administration of the test substances (Yadav et al., 2011).

Percentage (\%) analgesia was calculated as follows:

$\%$ Analgesia $=\left[\left(\mathrm{R}_{\mathrm{t}}-\mathrm{R}_{0}\right) / \mathrm{R}_{\mathrm{t}}\right] \times 100$

where $R_{t}=$ reaction time at any given interval after oral administration of plant extract or drug (Aspirin)

$\mathrm{R}_{0}=$ reaction time before oral administration of plant extract or drug (Aspirin) (Shanmugasundaram and Venkataraman, 2005; Shojaii et al., 2015; Dash et al, 2015)

\subsection{Data analysis}

For each group, the mean \pm SD of the reaction times of the mice were determined according to the method of Zimudzi et al., (2013) and the mean reaction time for each group $(n=5)$ was compared with the negative control group using t-test. Data for each time interval for the five groups (Tween 80, Aspirin (150 mg/kg bw), C. album (50, 100 and $150 \mathrm{mg} / \mathrm{kg}$ bw) were statistically analysed by the Tukey's multiple comparisons test using one-way analysis of variance (ANOVA) to determine if the mean reaction times of the five groups of mice at each time interval were significantly different from those of the negative control group and from each other. Levels of significance were set at $\mathrm{p}<0.05$. The statistical analyses were carried out using SPSS 16.0.

\section{RESULTS}

The yield of the crude leaf extract from the powdered leaf material after extraction with $95 \%$ methanol (v/v) in distilled water was $8.06 \%$.

\subsection{Toxicity test for $C$. album crude extract}

Expected signs of toxicity were mortality and slow movement of mice (Lalitha et al., 2010). No mortality was observed during the first 24 hours of observation and the next 14 days of monitoring for delayed toxicity even at the maximum administered extract dose of $5000 \mathrm{mg} / \mathrm{kg}$ bw (Group 5). The $\mathrm{LD}_{50}$ was therefore estimated to be higher than $5000 \mathrm{mg} / \mathrm{kg}$ bw.

\subsection{Antinociceptive activity of Chenopodium album crude leaf extract}

In Table 1 is presented the results of comparison of differences between hot plate latencies (as mean response times) and percent analgesia in the negative control group and test groups (Aspirin and C. album extract at different concentrations) as well as between test groups themselves, at the seven different time intervals of the experiment. At any time interval within the 360 minute period of monitoring, the response times of the mice to nociception increased with increasing dosage of extract, i.e. were dose dependent (Ashidi et al., 2015). The longer the response time (i.e., hot plate latency) the more analgesic the extract or drug is (Abdullahi et al., 2013). The results of the Tukey's multiple comparisons analysis using ANOVA showed that the mean response times to the thermal stimulus of the Aspirin treated group and C. album $(150 \mathrm{mg} / \mathrm{kg} \mathrm{bw})$ extract treated group were significantly different $(p<0.05)$ from that of the negative control group at all the seven time intervals from 30 to 360 minutes. With reference to antinociception (as \% analgesia) the test substances, Aspirin (150 mg/kg bw) and C. album crude leaf extract at $100 \mathrm{mg} / \mathrm{kg}$ bw and at $150 \mathrm{mg} / \mathrm{kg}$ bw produced significant $(\mathrm{P}<0.05)$ antinociception (as $\%$ analgesia) at all the seven time intervals when compared with the negative control. However, 50 $\mathrm{mg} / \mathrm{kg}$ bw $C$. album extract treated group produced significant $(\mathrm{P}<0.05)$ antinociception (as \% analgesia) only at 120,180 and at 240 minutes after administration of the crude extract. Table 1 also shows that between 30 and 180 minutes after oral administration of test substances at the dose of 150 $\mathrm{mg} / \mathrm{kg}$ bw C. album extract, antinociception (as \% 
analgesia) was statistically $(\mathrm{P}<0.05)$ not different from that induced by Aspirin. The highest antinociceptive response $(71.47 \%)$ in mice treated with $C$. album extract was observed with $150 \mathrm{mg} / \mathrm{kg}$ bw, at 30 minutes after administration of the crude extract; statistically $(\mathrm{P}<0.05)$ not different from that with Aspirin (67.44\%) at the same time interval.

In Figure 1 is presented the curves of the hot plate latencies for the three concentrations of $C$. album leaf extract and the reference drug Aspirin against time. Treatment with $C$. album leaf extract increased the response time of mice to thermal stimulus in a dose dependent manner with the group treated with 150 $\mathrm{mg} / \mathrm{kg}$ bw showing the longest response times at any given time interval.

In Figure 2 is represented the calculated percent (\%) analgesia based on the observed hot plate latencies for each of the three concentrations of $C$. album leaf extract with time. Beyond the $180^{\text {th }}$ minute of administration the reference drug Aspirin remained more efficacious than the $C$. album extract (at all concentrations), as reflected by the steep slope of the gradient up to 240 minutes. After the $240^{\text {th }}$ minute, the $\%$ analgesia curves for both $C$. album extract $(150 \mathrm{mg} / \mathrm{kg} \mathrm{bw})$ and Aspirin remained nearly-parallel, with the $C$. album curve shifted to the left of the Aspirin curve till the end of experiment at 360 minutes; this observation suggested a similar mechanism of antinociception. However, $50 \mathrm{mg} / \mathrm{kg}$ bw $C$. album extract produced the lowest antinociceptive responses compared to Aspirin at all the seven time intervals.

\section{DISCUSSION}

In the present study, the crude methanolic extract of leaves of Chenopodium album, used for the treatment of several ailments in Lesotho traditional medical practice, was assessed for toxicity and central antinociceptive activity by the hot plate assay using mice.

This study demonstrated that systemic administration of $C$. album crude extract at doses that did not produce any toxicity resulted in consistent dosedependent antinociceptive effects using the hot plate test in mice. The oral administration of a maximum dose of $5 \mathrm{~g} / \mathrm{kg}$ bw of $C$. album leaf extract did not produce any signs of acute toxicity or delayed toxicity in any of the mice during the observation period. This suggested that the median lethal oral dose $\left(\mathrm{LD}_{50}\right)$ of the extract was greater than $5 \mathrm{~g} / \mathrm{kg}$ bw. The fact that the $\mathrm{LD}_{50}$ of the extract was above $5 \mathrm{~g} / \mathrm{kg}$ bw was an indication that the extract could be considered nontoxic, when given orally (Kennedy et al., 1986; Obidah et al. 2014). The doses used in the hot plate test were therefore; $150 \mathrm{mg} / \mathrm{kg} \mathrm{bw}, 100$ and $50 \mathrm{mg} / \mathrm{kg}$ bw. The chosen doses were in agreement with those of Kataria et al.2012.

The hot plate test produces two kinds of behavioural response; paw licking and jumping, both of which are said to be supraspinally integrated responses (Chapman et al., 1985). Centrally acting analgesic agents can increase reaction time in the hot plate test through their action at the spinal cord level (Mondal et al., 2014); Battacharya et al., 2014, Rajashekar and Naraismamurthy, 2017. Experimental data represented in Table 1 and in Figures 1 and 2, indicate that $C$. album crude leaf extract exhibited central analgesic activity by increasing the latency to discomfort in the hot-plate test in a dose-dependent manner. Since the thermally induced nociception in the hot plate test is considered to be a selective method used to screen for centrally acting opiate analgesic drugs (Abbott, 1982), the effect of the $C$. album extract on this pain model indicated that it might be centrally acting.

The C. album leaf extract (at all concentrations) inhibited nociception starting at 30 minutes after administration of extract till 360 minutes when the experiment ended; though inhibition of nociception began to slow down gradually after one hour of administration of the extracts. Maximum antinociception occurred between 30 to 60 minutes after administration of the agent for all treatments (Aspirin and C. album). This was in agreement with findings from other authors (Ismail and Mirza, 2017; Ashidi et al., 2015, Jami et al., 2014). Ismail and Mirza, 2017 reported that, based on hot plate latencies, the aqueous leaf extracts of Lactuca sativa (lettuce) $1 \mathrm{~g} / \mathrm{kg}$ bw administered orally to rats and the reference drug Aspirin (10mg/kg bw) exhibited significant maximum analgesic activity compared to the negative control (saline) at one hour (of the 2 hour experiment) after administration after which it began to decline. Significant analgesic activity based on hot plate latencies (17.6 sec for the leaf extract and $17.8 \mathrm{sec}$ for Aspirin) in comparison to the negative control (saline) $5.4 \mathrm{sec}$ was observed at one hour after which it began to decline. Ashidi et al., 2015 reported that oral administration of the ethanolic extract of Elytraria marginata (Acanthaceae) prepared from the whole plant $(50,100$ and 150 $\mathrm{mg} / \mathrm{kg} \mathrm{bw}$ ) and the reference drug Ibuprofen (100 $\mathrm{mg} / \mathrm{kg} \mathrm{bw}$ ) to rats significantly reduced pain induced by the hot plate in all experimental groups when compared to the negative control (water). The effect of the extract at $150 \mathrm{mg} / \mathrm{kg}$ bw $(72.46 \%$ inhibition of pain) was statistically comparable to that of 
Ibuprofen $(100 \mathrm{mg} / \mathrm{kg} \mathrm{bw}) ; 67.15 \%$ inhibition of pain after one hour at which the experiment was terminated. Jami et al., 2014 reported that in an experiment using the hot plate test, oral administration of the ethanolic extract of Terminalia chebula fruit to mice at doses of $250 \mathrm{mg} / \mathrm{kg}$ and 500 $\mathrm{mg} / \mathrm{kg}$ induced a significant increase in reaction time compared to the negative control (water) group at 30 and 60 minutes (of the 180 minute experiment) after extract and drug administration which was statistically comparable to the standard drug Ketorolac $\quad(8.542 \pm 0.228$ and $9.483 \pm 0.309$ respectively). The maximum reaction time was observed at 30 minutes for both 250 and $500 \mathrm{mg} / \mathrm{kg}$ body weight $(11.133 \pm 1.388$ and $9.217 \pm 1.122$ respectively) compared with the negative control (8.117 \pm 0.897 and $7.97 \pm 1.010$ respectively).

As indicated by results of the Tukey's multiple comparisons analysis, the efficacy of the maximum concentration of $150 \mathrm{mg} / \mathrm{kg}$ bw C. album extract was not different from that of Aspirin $(150 \mathrm{mg} / \mathrm{kg} \mathrm{bw})$ from 30 minutes to 180 minutes after administration of the test substances. Similarly, Chyad, 2017 using the hot plate test on mice orally treated with the ethanolic extract of Lepidium draba leaves (dose range $100-500 \mathrm{mg} / \mathrm{kg}$ bw) observed maximum hot plate latencies at two hours (end of experiment) after administration of the highest doses 400 (15.98 sec from $7.01 \mathrm{sec})$ and $500 \mathrm{mg} / \mathrm{kg} \mathrm{bw}(16.12 \mathrm{sec}$ from $6.98 \mathrm{sec}$ ) and Aspirin $100 \mathrm{mg} / \mathrm{kg}$ bw (18.01 sec from $7.03 \mathrm{sec})$ were significantly higher than those of the negative control (saline; $8.77 \mathrm{sec}$ ) at $\mathrm{p}<0.05$. Only hot plate latencies were used by this author.

The fact that the response times to nociception as shown in Figure 1 (and hence $\%$ analgesia in Figure 2) peaked during the same time period (from 30 minutes to 60 minutes) for the C. album extract (at all the concentrations) and for Aspirin indicated similar rates of absorption from the stomach and small intestine (GI tract) and build-up of the pharmacologically active phytochemicals in the blood plasma of mice (Brunton et al., 2008). Figure 2 also shows that beyond 180 minutes, antinociception (as \% analgesia) with $C$. album extract $(150 \mathrm{mg} / \mathrm{kg}$ bw) declined at a faster rate than with Aspirin (150 $\mathrm{mg} / \mathrm{kg} \mathrm{bw}$ ); this trend continued up to 240 minutes, meaning that the active constituent of Aspirin in plasma (salicylate) was inactivated by the liver or used up more slowly than those in $C$. album extract; the serum half-life of active compound of Aspirin being longer than that of the active compounds in $C$ album crude extract (Brunton et al., 2008. Higuchi et al.,(1986) reported that salicylic acid (the active compound in Aspirin) may produce its analgesic action via a central mechanism. A crude extract may contain active compounds in small amounts and these may act either synergistically or individually if very potent; on the other hand, the plant extract might have few active compounds in large amounts that act individually or synergistically to exert its therapeutic efficacy (Barton and Ollis, 1985). After the $240^{\text {th }}$ minute, the $\%$ analgesia curves for both $C$. album extract $(150 \mathrm{mg} / \mathrm{kg} \mathrm{bw})$ and Aspirin remained almost parallel; with the $C$. album curve shifted to below the Aspirin curve till the end of the experiment at 360 minutes, Aspirin remaining more efficacious indicating that the active compound in Aspirin was metabolized more slowly to its inactive form (Brunton et al., 2008) compared to C. album active constituents; but no difference in mode of antinociception between them. The observed antinociceptive responses of mice after treatment with $C$. album extract and Aspirin in the hot plate test suggested that the extract acted in a similar manner to Aspirin which is also known to exhibit central analgesic effects (Bromm et al., 1991; Zimudzi et al., 2013; Higuchi et al., 1986).Considering that $C$. album was a crude extract while Aspirin was a pure drug (active compound acetylsalicylic acid), $C$. album compared well with Aspirin in antinociception. It is reported that $C$. album is hepatoprotective (Pal et al., 2011) and antiulcerogenic (Nigam and Paarakh, 2011; Biswas, 2013). The main side-effect of NSAIDs is their ability to produce gastric lesions (Brunton et al., 2008). Chenopodium album has also been found to possess more effective hepatoprotective activity against Paracetamol intoxication in rats because of its flavonoid bearing capacity (Pal et al., 2011).

Results of the study by Zimudzi et al., (2013) using the hot plate assay showed that intraperitoneal administration of Dicoma niccolifera extract (1000, 500,250 and $125 \mathrm{mg} / \mathrm{kg} \mathrm{bw}$ ) increased the pain threshold in mice in a similar way to Aspirin $(200 \mathrm{mg} / \mathrm{kg} \mathrm{bw})$, which indicated that the activity may be through a centrally mediated analgesic mechanism. Some of the phytochemicals (flavonoids, tannin, alkaloids, terpenoids, anthraquinones) known to exhibit central analgesic activity were identified in D. niccolifera by these authors. In agreement with the findings of Zimudzi et al., 2013, the C. album leaf extract used in this study increased reaction times of mice to the nociceptive thermal stimulus in a dosedependent manner. The findings of our study using the hot plate test also indicated that the central analgesic activity of the $C$. album leaf extract may be linked partly to the reported presence of simple phenols and polyphenols, terpenoids, alkaloids (Sikarwar et al., 2013; Agrawal et al., 2014; Kumar and Kumar 2015) all of which are known to have antinociceptive effects. Aromatic compounds are 
reported to constitute up to $60.1 \%$ of the phytochemical composition of $C$. album leaf extractives (Agrawal et al., 2014). The presence of phenolics, such as flavonoids, coumarins and tannins, steroids, alkaloids, terpenoids such as triterpenoids like terpenoid saponins in plant extracts is reported to enhance the centrally mediated response to pain in a dose-dependent manner (Abdullahi et al., 2013; Jami et al., 2014, Abdullahi et al., 2016; Bagheri et al., 2017; Sajeesh and Parimelazhagan, 2014; Barua et al., 2010; Shojaii et al., 2015). In our study, the pharmacologically active phytochemicals in the $C$. album extract might have acted on the central opioid receptors or promoted release of endogenous opioid peptides to inhibit central nociception (Le Bars et al., 2001).

The present study showed that the antinociceptive efficacy of C. album extract at $150 \mathrm{mg} / \mathrm{kg}$ bw p.o.was statistically not different from that of Aspirin from 30 minutes to 180 minutes; after which the mechanism of action remained similar though antinociceptive activity became lower. Studies by other authors indicated that $C$. album extract exhibited peripheral analgesic and anti-inflammatory activity (TrivellatoGrassi et al., 2013), significant reduction of the ulcer index (Nigam and Paarakh, 2011), preservation of the gastric mucosa (not observed with many NSAIDs) and hepatoprotective effects (Pal et al., 2011). The observations listed above suggest that there is a potential to develop extracts of $C$. album as non-toxic natural analgesics (Ulrich-Merzenich et al., 2010).

\section{CONCLUSION}

The toxicity tests showed that Chenopodium album leaf extract was not toxic at oral doses of up to 5000 $\mathrm{mg} / \mathrm{kg}$ bw during the 14 day observation period. The crude leaf extract of $C$. album possessed significant dose-dependent central antinociceptive effects at the dosage range of $50-150 \mathrm{mg} / \mathrm{kg}$ bw in mice as it increased the pain threshold in a similar manner to Aspirin. At $150 \mathrm{mg} / \mathrm{kg}$ bw, the efficacy of C. album extract was statistically not different from that of Aspirin $(150 \mathrm{mg} / \mathrm{kg} \mathrm{bw})$ for the first 180 minutes.

\section{FUNDING}

This work was supported by a Research grant provided by the Research and conference committee, National University of Lesotho, 2016/2017.

\section{REFERENCES}

1. Abbott FV, Melzack R, Brainstem lesions dissociate neural mechanisms of morphine analgesia in different kinds of pain. Journal of Brain Research, 1982; 251(1), 149-155.

2. Abdullahi MN, Ilyas $\mathrm{N}$ and Ibrahim H.Evaluation of phytochemical screening and analgesic activity of aqueous extract of the leaves of MicrotrichiaperotitiiDc(Asteraceae) in mice using hotplate method. Medicinal Plant Research, 2013; 3(5): 37-43.

3. Abdullahi, Z. Jimmoh, AA. Patrick EB. Analgesic, Antiinflammatory and Anti-pyretic activities of Tapinanthusdodoneifolius (DC) Danser extract using several experimental models of rodents. Journal of Biology and Genetic Research,2016; 2(1):46-56.

4. Agrawal Mona $\mathrm{Y}$, Agrawal Yogesh $\mathrm{P}$ and Shamkuwar Prashant B. Phytochemical and Biological Activities of Chenopodium album. International Journal of PharmTech Research,2014; 6 (1): 383-391.

5. Ahmad M, Mohiuddin OA, MehjabeenJahan N, Anwar M, Habib S, Alam SM, Baig IA. Evaluation of spasmolytic and analgesic activity of ethanolic extract of Chenopodium album Linn and its fractions. Journal of Medicinal Plants Research, 2012; 6(31):4691-7.

6. Almeida RN, Navarro DS, Barbosa-Filho JM. Plants with central analgesic activity. Phytomedicine, 2001; 8:310-322.

7. Ashidi JS,Ojetola OJ,Aziba PI and Ajaiyeoba EO. Analgesic and anti-inflammatory effects of the ethanol extract of Elytraria marginata Vahl (whole plant) in Wistar rats. Journa of Pharmacognosyand Phytotherapy,2015; 7(7):126-131.

8. Asita AO, Dingaan ME, Magama S. Lack of modulatory effect of asparagus, tomato, and grape juice on cyclophosphomide-induced genotoxicity in mice. African Journal of Biotechnology, 2008; 7 (18):3383-3388.

9. Bagheri SM, Mohamadsadeghi H, Hejazian ES Antinociceptive effect of seed's essential oil of Ferula assafoetida in Mice. International Journal of Clinical and Experimental Physiology,2017; 4(1):34-37.

10. Barton D,and Ollis WD. Advances in Medicinal Phytochemistry. Proceedings of the International Symposium held in Marrakesh 17-18 January 1985. Organised by De Recherche Pierre Fabre. J. LibbeyEurotext.

11. Barua CC, Talukdar A, Begum SA, Lahon LC, Sarma DK, Pathak DC and Borah P.Antinociceptive activity of methanolic extract of leaves of Achyranthesa spera Linn. (Amaranthaceae) in animal models of nociception. Indian Journal of Experimental Biology, 2010; 48:817-821.

12. Begum S, Morshed T, Harun-or-Rashid, Walid R, Debnath K, Roney SI, Rahmatullah M. Antinociceptive activity of Chenopodium album L., (Chenopodiaceae) whole plants. Advances in Natural and Applied Sciences 2013;7(2):138142.

13. Bhattacharya A, Agrawal D, Sahu PK, Kumar S, Mishra SS and Patnaik S. Analgesic effect of ethanolic leaf extract of Moringa oleifera on albino mice. Indian Journal of Pain, 2014; 28 (2):89-94.

14. Biswas MK, Mridha SA, Rashid MA and Sharmin $T$. Membrane stabilizing and antimicrobial activities of Caladium bicolor and Chenopodium album. IOSR Journal of Pharmacy and Biological Sciences,2013; 6(5):62-65.

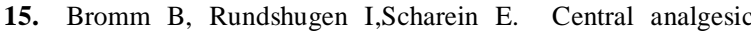
effects of acetylsalicylic acid in healthy men. Arzneimittelforschung, 1991; 41(11):1123-1129.

16. Brunton LL, Parker KL, Blumenthal DK, Buxton ILO. Goodman and Gilman's Manual of Pharmacology and Therapeutics. McGraw-Hill. 2008. Doi:10.1036/0071443436.

17. Chapman CR, Casey KL, Dubner R, Foley DM, Graceley RH, Reading AE. Pain measurement: an overview. Pain, $1985 ; 22: 1-31$

18. Chyad AH. Evaluation of anticancer, analgesic and antiinflammatory activities of the ethanolic extract of Lepidium draba Linn. leaves. Advances in Animal and Veterinary Sciences, 2017;5(1):7-13.

19. Dai Y, Ye WC, Wang ZT, Matsuda H, Kubo M, But PPH. Antipruritic and antinociceptive effects of Chenopodium album L. in mice. Journal of Ethnopharmacology, 2002; 81:245-250.

20. Dash PR, Rana S, Ali MS. Investigation of analgesic and cytotoxic activities of ethanol extract of Commelina 
appendiculata. Journal of Pharmacognosy and Phytochemistry, 2015;4(3):53-59.

21. Datta A, Bhalerao SV, Shidore PP, Tilak AV, Patil S and Deshpande T. To evaluate the analgesic efficacy of an ethanolic extract of Piper betle Linn. (paan) and its probable mechanism of action using animal models. Research Journal of Pharmaceutical, Biological and Chemical Sciences 2014; 5(3): 424-431.

22. Higuchi S, Tanaka N, Shioiri Y, Otomo S, Aihara H. The modes of analgesic action of aspirin, and the site of analgesic action of salicylic acid. International Journal of Tissue Reactions, 1986;8(4):327-331.

23. Ibironke GF, Ajiboye KI. Studies on the anti-inflammatory and analgesic properties of Chenopodium ambrosiodes leaf extract in rats. International Journal of Pharmacology, 2007; 3(1):111-115.

24. Ismail, H. Mirza, B. Evaluation of analgesic, antiinflammatory, anti-depressant and ant-coagulant properties of Lactuca sativa (CV. Grand Rapids) plant tissues and cell suspension in rats. BioMedCentral (BMC) Complementary and Alternative Medicine, 2015; 15: 199-205.

25. Jami SI, Sultana $Z$, Ali E, Begum $M$ and HaqueM. Evaluation of analgesic and anti-inflammatory activities on ethanolic extract of Terminalia chebula fruits in experimental animal models. American Journal of Plant Sciences, 2014; 5: 63-69.

26. Kataria S, Shrivastava B, Kaur D, Sharma P. Antiinflammatory and antinociceptive activities of Crotalaria burhia Buch.-Ham. whole plant. Indian Journal of Natural Products and Resources, 2012; 3(2):189-196.

27. Kaur S, Jaggi RK. Antinociceptive activity of chronic administration of different extracts of Terminalia bellerica Roxb. And Terminalia chebula Retz. fruits. Indian Journal of Experimental Biology, 2010; (48): 925-930.

28. Kennedy GL, Ferenz RL, Burgess BA. Estimation of acute oral toxicity in rats by determination of the approximate lethal dose rather than the LD50. J. Appl. Toxicol. 1986; 6148-148.

29. Kokanova-Nedialkova Z, Nedialkov PT and Nikolov SDThe genus Chenopodium: Phytochemistry, ethnopharmacology and pharmacology. Pharmacognosy Review, 2009;3(6):280306.

30. Kumar P, Kumar S. Phytochemistry, traditional uses, pharmacology of Indian medicinal plant Chenopodium album (LINN). World Journal of Pharmacy and Pharmaceutical Sciences, 2015;4(7):404-421.

31. Lalitha KG, Venkatachalam T, Rathinavel G, Kumar VK and Kalaiselvi P. Evaluation of analgesic activity of Evodialunuankenda (Gaertn) Merr. DerPharmaciaSinica2010;1(1):7-10.

32. Le Bars D, Gozariu M, Cadden S. Animal models of nociception. Pharmacological Reviews, 2001; 53:597-652

33. Linn B (1984). Cutaneous nociceptors. In: Holden, Winlow W. The Neurobiology ofPain. Manchester, UK. 1984; 106.

34. Maliehe EB and Oehrlein S. Medicinal plants and herbs of Lesotho: a visual guide to 60 species from around the country. 1997. Maseru, Lesotho: Mafeteng Development Project.

35. Mondal H, Saha S, Awang K, Hossain H, Ablat A, Islam K, Jahan IA, Sadhu SK, Hossain G, Shilpi JA, Uddin SJ. Central stimulating and analgesic activity of the ethanolic extract of Alternanthera sessilis in mice. BMC Complementary and Alternative Medicine, 2014; 14: 398-406.

36. Morales G, Paredes A, Olivares A and BravoJ. Acute oral toxicity and anti-inflammatory activity of hydroalcoholic extract from Lampaya medicinalis Phil in rats. Biological Research, 2014, 47(6):1-7.

37. Nigam V, Paarakh PM. Anti-ulcer Effect of Chenopodium album Linn. against gastric ulcers in rats. International
Journal of Pharmaceutical Sciences and Drug Research, 2011; 3(4): 319-322.

38. Obidah W, Badung HL, Ajuji J, Hakeino P and Bello $\mathrm{H}$ Effects of Erythrina senegalensis aqueous leaf extract in rats. American Journal of Research Communication, 2014;2(4):179-185.

39. Omeh YS and Ezeja MI. Analgesic activity of the methanolic leaf extract of Jatrophacurcas (Linn).African Journal of Biomedical Research, 2010;13:149-152.

40. Pal A, Banerjee $\mathrm{B}$, Banerjee $\mathrm{T}$, Masih $\mathrm{M}$, Pal K. Hepatoprotective activity of Chenopodium album Linn. plant against paracetamol induced hepatic injury in rats. International Journal of Pharmacy and Pharmaceutical Sciences, 2011; 3(3):55-57.

41. Rajalakshimi V, Gauthaman K, Alhazzani AA, Kamalraj R, Nisar N, Devdass G. Analgesic and anti-inflammatory evaluation of ethanolic extract of Seenthil churanam. International Journal of Pharmaceutical Sciences and Drug Research 2015;7(1):63-67.

42. Rajashekar, YR. Narasimhamurthy, KM. 2017. A comparative evaluation of analgesic and anti-inflammatory activities of two medicinal plants Rubia cordifolia and Cassia fistula in Wistar albino rats. International Journal of Basic \& Clinical Pharmacology,2017;6(4): 802-806.

43. Sajeesh $\mathrm{T}$ and Parimelazhagan T.Analgesic, AntiInflammatory, and GC-MS Studies on Castanospermum austral A. Cunn. \& C. Fraser $e x$ Hook. The ScientificWorld Journal, 2014: 1-9.

44. Schaible HG. Peripheral and Central mechanisms of Pain Generation. HEP. 2006. 177:3-28. Springer-Verlag. Berlin Heidelberg. In: Analgesia. Stein, C. (Ed.) 2007, VIII, 435p.Springer. http://www.springer.com/978-3-540-33822-2.

45. Shanmugasundaram $P$ and Venkataraman S. Anti-nociceptive activity of Hygrophila auriculata (Schum) Heine. African Journal of Traditional,Complementary and Alternative Medicines, 2005; 2 (1):62- 69.

46. Shojaii, A, Motaghinejad, M. Norouzi, S. Motevalian, M. Evaluation of anti-inflammatory and analgesic activity of the extract and fractions of Astragalus hamosus in animal models. Indian Journal of Pharmaceutical Research 2015; 14 (1):263-269.

47. Sikarwar I, Wanjari M, Baghel SS and Vashishtha PA. Review on Phytopharmacological Studies on Chenopodium album Linn. Indo American Journal of Pharmaceutical Research, 2013;3(4): 3089-3098.

48. Tripathi KD. Essentials of Medical Pharmacology. Jaypee Brothers Medical Publishers. New Delhi, India, $5^{\text {th }}$ edition. 2004.

49. TrivellatoGrassi L, Malheiros A, Meyre-Silva C, da Silva Buss Z, DalmarcoMonguilhott E, Fröde TS, da Silva KABS, de Souza MM. From popular use to pharmacological validation: A study of the anti-inflammatory, anti-nociceptive and healing effects of Chenopodium ambrosioides extract. Journal of Ethnopharmacology, 2013; 145: 127-138.

50. Ulrich-Merzenich G, Panek D, Zeitler H, Vetter H, Wagner H. Drug development from natural products: Exploiting synergistic effects. Indian Journal of Experimental Biology. 2010; (48):208-219.

51. Yadav R D, Jain SK, Alok S and Sharma S. Analgesic activity of ethanolic extract of Pongamia pinnata Linn. leaves. Der Pharmacia Lettre 2011; 3(5): 179-182.

52. Zimudzi C, Rupende K, Kativu S, Jere J and Kunonga NI. Phytochemical and analgesic activity of root crude extracts of Dicoma niccolifera Wild (Asteraceae). Journal of Applied Pharmaceutical Science, 2013; 3 (04): 165-168.

53. Zulfiker AHM, Mahbubur Rahman M, Kamal Hossain M, Hamid K, Mazumder MEH, SohelRana M. In vivo analgesic activity of ethanol extracts of two medicinal plants Scoparia dulcis L. and Ficus racemosa Linn. Biology and Medicine, 2010; 2(2): 42-48. 
Evaluation of Chenopodium album Linn. Crude Methanolic Leaf Extract for Central Antinociceptive Activity in Albino Mice using the Hot Plate Test

\section{TABLES AND FIGURES}

Table 1. Mean reaction times of mice given different doses of Chenopodium album leaf extracts $(n=5, \pm$ S.D $)$

\begin{tabular}{|c|c|c|c|c|c|c|}
\hline & & & \multicolumn{3}{|c|}{ Doses of extract $(\mathrm{mg} / \mathrm{kg}$ body weight } & ANOVA \\
\hline $\begin{array}{l}\text { intervals } \\
\text { (Minutes) }\end{array}$ & $\begin{array}{c}\text { Tween-80 } \\
(5 \mathrm{~mL} / \mathrm{kg} \mathrm{bw})\end{array}$ & $\begin{array}{c}\text { Aspirin } \\
(150 \mathrm{mg} / \mathrm{kg} \mathrm{bw})\end{array}$ & 50 & 100 & 150 & $\begin{array}{l}\text { Intervals F } \\
\text { Values }\end{array}$ \\
\hline 0 & $1.97 \pm 0.18 \mathrm{a}$ & $\begin{array}{c}2.05 \pm 0.27 \mathrm{a} \\
(0.00)\end{array}$ & $\begin{array}{c}2.12 \pm 0.15 \mathrm{a} \\
(0.00)\end{array}$ & $\begin{array}{c}2.31 \pm 0.55 \mathrm{a} \\
(0.00)\end{array}$ & $\begin{array}{c}1.87 \pm 0.17 \mathrm{a} \\
(0.00)\end{array}$ & 1.54 \\
\hline 30 & $2.34 \pm 0.44 \mathrm{a}$ & $\begin{array}{c}\neq 6.28 \pm 0.73 b c \\
\left(67.44^{*}\right) \\
\end{array}$ & $\begin{array}{c}2.57 \pm 0.33 \mathrm{ad} \\
(17.51) \\
\end{array}$ & $\begin{array}{c}\neq 5.03 \pm 0.75 \mathrm{e} \\
\left(53.96^{*}\right) \\
\end{array}$ & $\begin{array}{c}\neq 6.55 \pm 0.48 \mathrm{~b} \\
\left(71.47^{*}\right) \\
\end{array}$ & $61.5 \#$ \\
\hline 60 & $2.38 \pm 0.35 \mathrm{a}$ & $\begin{array}{c}\neq 6.75 \pm 0.87 \mathrm{~b} \\
(69.69 *) \\
\end{array}$ & $\begin{array}{c}2.98 \pm 0.63 \mathrm{a} \\
(28.76)\end{array}$ & $\begin{array}{c}\neq 5.55 \pm 0.56 b \\
\left(58.32^{*}\right) \\
\end{array}$ & $\begin{array}{c}\neq 6.38 \pm 0.79 \mathrm{~b} \\
\left(70.70^{*}\right) \\
\end{array}$ & 45.41\# \\
\hline 120 & $2.18 \pm 0.19 \mathrm{a}$ & $\begin{array}{c}\neq 6.01 \pm 0.24 b \\
\left(65.98^{*}\right)\end{array}$ & $\begin{array}{c}\ddagger 3.00 \pm 0.33 c \\
\quad\left(29.38^{*}\right)\end{array}$ & $\begin{array}{c}\neq 4.63 \pm 0.61 \mathrm{~d} \\
\left(50.06^{*}\right) \\
\end{array}$ & $\begin{array}{c}\neq 5.57 \pm 0.53 b \\
\left(66.44^{*}\right)\end{array}$ & 78.42\# \\
\hline 180 & $2.22 \pm 0.18 \mathrm{a}$ & $\begin{array}{c}\neq 5.71 \pm 0.56 b \\
\left(64.14^{*}\right) \\
\end{array}$ & $\begin{array}{c}\ddagger 2.84 \pm 0.15 \mathrm{a} \\
\left(25.46^{*}\right)\end{array}$ & $\begin{array}{c}\ddagger 4.63 \pm 0.98 \mathrm{c} \\
\left(50.06^{*}\right)\end{array}$ & $\begin{array}{c}\neq 5.19 \pm 0.44 b, c \\
\left(66.04^{*}\right)\end{array}$ & 37.80\# \\
\hline 240 & $2.13 \pm 0.15 \mathrm{a}$ & $\begin{array}{c}\neq 4.69 \pm 0.63 b \\
\left(56.41^{*}\right) \\
\end{array}$ & $\begin{array}{c}\neq 2.97 \pm 0.38 \mathrm{a}, \mathrm{c} \\
\left(28.52^{*}\right)\end{array}$ & $\begin{array}{c}\neq 4.65 \pm 0.85 b \\
\left(50.19^{*}\right) \\
\end{array}$ & $\begin{array}{c}\neq 3.53 \pm 0.40 \mathrm{c}, \mathrm{d} \\
\left(47.05^{*}\right)\end{array}$ & 20.85\# \\
\hline 300 & $2.13 \pm 0.09 \mathrm{a}$ & $\begin{array}{c}\neq 4.47 \pm 0.67 \mathrm{~b} \\
\left(54.27^{*}\right)\end{array}$ & $\begin{array}{c}2.51 \pm 0.50 \mathrm{a}, \mathrm{d} \\
(15.47)\end{array}$ & $\begin{array}{c}\ddagger 2.74 \pm 0.66 \mathrm{a}, \mathrm{d} \\
\left(15.67^{*}\right)\end{array}$ & $\begin{array}{c}\ddagger 3.19 \pm 0.57 \mathrm{c}, \mathrm{d} \\
\left(41.48^{*}\right)\end{array}$ & 14.00\# \\
\hline 360 & $2.18 \pm 0.03 a$ & $\begin{array}{l}\neq 3.72 \pm 0.38 \mathrm{~b} \\
\quad\left(44.94^{*}\right)\end{array}$ & $\begin{array}{c}\ddagger 2.50 \pm 0.34 \mathrm{a}, \mathrm{c} \\
(15.06)\end{array}$ & $\begin{array}{c}2.26 \pm 0.27 \mathrm{a}, \mathrm{c} \\
\left(-2.48^{*}\right)\end{array}$ & $\begin{array}{c}\neq 2.71 \pm 0.44 \mathrm{a}, \mathrm{c} \\
(31.02 *)\end{array}$ & $18.01 \#$ \\
\hline
\end{tabular}

Numbers in parenthesis are percentages of pain inhibition; * = Percent (\%) inhibition of pain was significant compared to the negative control; \# = Mean response time of control and four treatments, at the given time interval, where $n=5$ in each case, is statistically significant $\left(\mathrm{F}_{4,20}=2.866, \mathrm{P}<0.05\right) ; \uparrow=$ Means with the same letter do not differ statistically at the level of 0.05 for each time interval; $\neq=$ Mean response time significantly higher than that of the control group in the $t$-test 

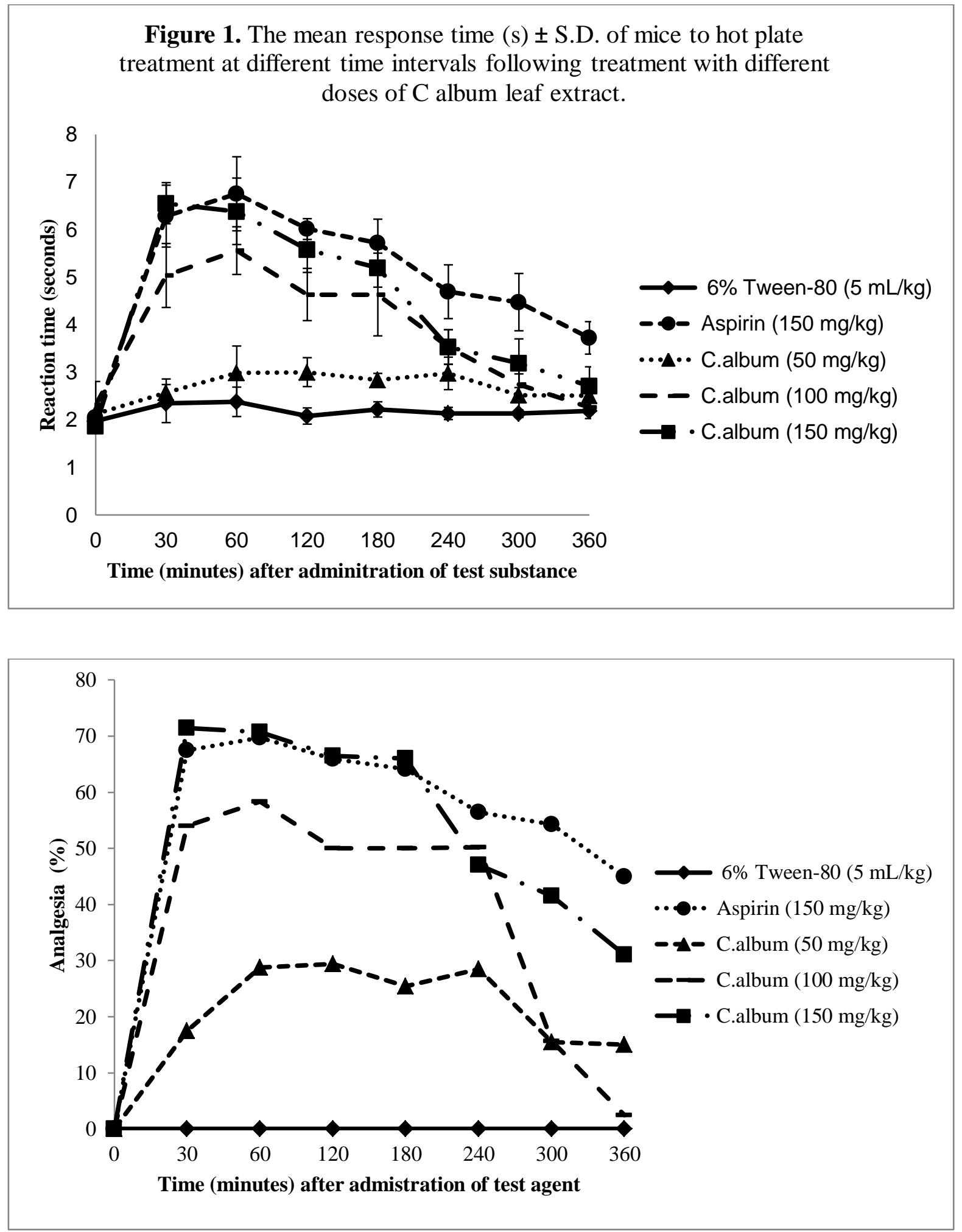

Figure 2: Percentage analgesia in mice in the Eddy's hot plate test following treatment with different doses of $C$. album leaf extract, vehicle (Tween-80) and reference drug (Aspirin) at different time intervals. 